\title{
Association of interleukin - 18 gene polymorphism with susceptibility or protective effect to HTLV-1 infection
}

\author{
Virgínia M D Wagatsuma ${ }^{1 *}$, Daiani C Cilião-Alves ${ }^{2}$, Maurício C Rocha-Junior ${ }^{1,3}$, Rodrigo Haddad ${ }^{1,2}$, \\ Oswaldo M Takayanagui ${ }^{2}$, Eduardo A Donadi ${ }^{2}$, Dimas T Covas ${ }^{1,2}$, Simone Kashima ${ }^{1,3}$ \\ From 15th International Conference on Human Retroviruses: HTLV and Related Viruses \\ Leuven and Gembloux, Belgium. 5-8 June 2011
}

\section{Background}

Polymorphisms in promoter region of IL-18 genes have been studied in many chronic inflammatory and infectious disorders. For instance, the IL-18 -137 GG and $-607 \mathrm{CC}$ polymorphisms have been associated with elevated expression of IL-18, which could contribute for the inflammatory process and favor the antiviral effects of this cytokine. In this study, we evaluated the IL-18 promoter region $-137 \mathrm{C} / \mathrm{G}$ and $-607 \mathrm{~A} / \mathrm{C}$ polymorphisms in HTLV-infected patients exhibiting (HAM) or not (HAC) symptomatic disease and in healthy controls.

\section{Methods}

The promoter region polymorphic sites $(-137 \mathrm{C} / \mathrm{G}$ and $-607 \mathrm{~A} / \mathrm{C}$ ) were evaluated by polymerase chain reaction sequence specific primers (PCR-SSP) analysis using peripheral blood DNA obtained from HAC (54), HAM (44) and healthy control (150) individuals. Proviral load of infected patients (HAC and HAM) was determined by real-time PCR.

\section{Results}

The $-607 \mathrm{CC}$ genotype was less frequent for HAC group $(\mathrm{p}=0.0501 ; \mathrm{OR}=0.4890 ; \mathrm{CI}=0.2480$ to 0.9643$)$, and infected patients $(\mathrm{p}=0.0232 ; \mathrm{OR}=0.5207 ; \mathrm{CI}=0.3033$ to $0.8937)$ compared to healthy controls. The $-607 \mathrm{AC}$ genotype was more frequent for HAC group $(\mathrm{p}=0.0387$; $\mathrm{OR}=1.991 ; \mathrm{CI}=1.043$ to 3.801 ), and infected patients $(\mathrm{p}=0.0376 ; \mathrm{OR}=1.757 ; \mathrm{CI}=1.047$ to 2.948$)$ compared to healthy controls. No significant difference was observed for allelic and genotypic frequencies of the $-137 \mathrm{C} / \mathrm{G}$ among deferments groups. No significant difference was observed for allelic and genotypic frequencies of the $-137 \mathrm{C} / \mathrm{G}$ and $-607 \mathrm{~A} / \mathrm{C}$ polymorphisms when correlated with proviral load.

\section{Conclusion}

The -607CC (high producer of IL-18) genotype exhibited protective effect against the infection, whereas the -607AC genotype conferred susceptibility to HTLV-1 infection.

\section{Acknowledgements \\ Financial Support: FAPESP, CNPq, CTC/FUNDHERP and INCTC.}

\section{Author details}

${ }^{1}$ Regional Blood Center of Ribeirão Preto, Ribeirão Preto, Brazil. ${ }^{2}$ Faculty of Medicine of Ribeirão Preto, University of São Paulo, Ribeirão Preto, Brazil. ${ }^{3}$ Faculty of Pharmaceutical Sciences of Ribeirão Preto, University of São Paulo, Ribeirão Preto, Brazil.

Published: 6 June 2011

doi:10.1186/1742-4690-8-S1-A118

Cite this article as: Wagatsuma et al:: Association of interleukin - 18 gene polymorphism with susceptibility or protective effect to HTLV-1 infection. Retrovirology 2011 8(Suppl 1):A118.

* Correspondence: virgmara@gmail.com

${ }^{1}$ Regional Blood Center of Ribeirão Preto, Ribeirão Preto, Brazil

Full list of author information is available at the end of the article 